\title{
ANALISIS TINGKAT PARTISIPASI MASYARAKAT DALAM PENCEGAHAN PENYEBARAN COVID-19 DI WILAYAH KERJA PUSKESMAS BIRU KAB. BONE
}

\author{
Kistan $^{1 *}$, Najman ${ }^{2}$ \\ ${ }^{1,2}$ Program Studi D3 Keperawatan, Akademi Keperawatan Batari TojaWatampone, Jl. Poros Majang \\ No.17, Kabupaten Bone, Sulawesi Selatan 92734, Indonesia \\ email: ners.kistan155@gmail.com ${ }^{1}$
}

Diterima : November 2021, Diterbitkan : Desember 2021

\begin{abstract}
ABSTRAK
Pada dasarnya Pencegahan Penyebaran COVID-19 ini bukan hanya menjadi tanggung jawab pemerintah melainkan seluruh komponen masyarakat baik muncul dari kesadaran sendiri maupun melihat dari asas manfaatnya. Tujuan dari penelitian ini adalah untuk mengetahui partisipasi masyarakat dimulai dari perencanaan, pelaksanaan, penerimaan manfaat dan pengawasan dalam pencegahan penyebaran COVID-19. Penelitian ini merupakan penelitian Deskriktif kuantitatif dengan jenis penelitian teknik Analisis statistik deskriktif dan Analisis Korelasi spearman rank. Sebanyak 397 masyarakat Wilayah kerja Puskesmas Biru yang terdiri dari 8 kelurahan menjadi responden.Teknik Sampling yang digunakan adalah Simple random sampling. Pengumpulan data dengan menggunakan koesioner. Analisis menunjukkan Partisipasi masyarakat wilayah kerja Puskesmas Biru dimulai dari keterlibatan masyarakat dalam perencanaan 0,466 dengan terlibat dalam sosialisasi dan setuju dengan penerapan Protokol kesehatan, keterlibatan masyarakat dalam pelaksanaan 0,599 dengan menerapkan protocol kesehatan physical Distancing, Self Quarantine dan Self Isolasi, keterlibatan masyarakat dalam penerimaan manfaat 0,477 dengan merasa aman jika menerapkan protokol kesehatan dan keterlibatan masyaraka tdalam pengawasan 0,257 yaitu dengan dengan saling mengawasi antar warga untuk patuh protokol kesehatan dan melapor jika ada masyarakat luar yang masuk lingkungan masyarakat atau dengan memantau masyarakat yang dianjurkan untuk isolasi mandiri atau ada warga yang terkonfirmasi atau belum COVID-19. Dari hasil Uji Korelasi Spearman diperoleh bahwa nilai $r$ hitung $>$ dari $(0,25-0,5)$ yang berarti Partisipasi masyarakat memiliki kekuatan hubungan yang cukup kuat dengan pencegahan penyebaran COVID-19 dengan nilai signifikan yang diperoleh dari setiap variable $0,000<$ sig 0,05 yang berarti hubungan antar variable mempunyai dua arah (2-tailed) dan bernilai positif yang berarti semakin tinggi tingkat partisipasi masyarakat maka semakin tinggi pula pencegahan penyebaran COVID-19. Kata kunci:Partisipasi masyarakat, Pencegahan Penyebaran COVID-19
\end{abstract}

\section{ABSTRACT}

Based on the prevention of the spread of COVID-19, it is not only the responsibility of the government but all components of society, both arising from their own awareness and seeing the benefits principle. The purpose of this study was to determine community participation starting from planning, implementing, receiving benefits and monitoring in preventing the spread of COVID-19. The method used descriptive quantitative method, with the type of analytical survey statistical with descriptive statistical analysis techniques and Spearman rank correlation analysis. A total of 397 people in the Biru Public Health center area consisting of 8 sub-districts became respondents in this study. The sampling technique used is simple random sampling. Data collection using questionnaires The results of the analysis show that community participation in the Blue Health Center work area starts from community involvement in planning (0.466) by being involved in socialization and agreeing with the implementation of health protocols, community involvement in implementation $(0.599)$ by implementing physical distancing, self-quarantine and self-isolation health protocols, community involvement in receiving benefits $(0.477)$ by feeling safe if applying health protocols and community involvement in supervision (2.57) by supervising each other between residents to comply with health protocols and reporting if there are outsiders who enter the community environment or by monitoring the recommended community for self-isolation or there are residents who are confirmed or not COVID-19. The results of the Spearman Correlation Test, it was found that the value of $r$ calculated $>$ from $(0.25-0.5)$ which means that community participation has a fairly strong relationship with preventing the spread of COVID-19 with a significant value obtained from each variable $0.000<\operatorname{sig} 0,05$ which means the relationship between 
variables has two directions (2-tailed) and is positive, which means the higher the level of community participation, the higher the prevention of the spread of COVID-19.

Keywords: Community participation, Prevention of the Spread of COVID-19

\section{PENDAHULUAN}

Virus COVID-19 Muncul pertama kali pada awal Desember 2019 Wuhan, Ibu kota Hubei di Cina Tengah hingga menyebar secara cepat hampir seluruh dunia. Sedangkan di Indonesia dimulai pada bulan maret 2020 saat ditemukan pertama kali kasus di Kota Depok dan pada bulan yang sama melalui Keputusan Presiden RI No 11 Tahun 2021 menetapkan COVID-19 sebagai Bencana Kesehatan (KEPRES, 2020).

Hingga saat ini dari Data World Health Organization WHO (2020), pada 21 September sudahtercatat 30.949 .804 yang terkonfirmasipositif, sebanyak 959.115 yang meninggaldan 272.585 ditemukan kasus baru di seluruh dunia. Sedangkan di Indonesia tercatat 248.852 kasus, 180.797 dinyatakan sembuh dan 9.677 meninggal dunia. Hal ini menjelaskan bahwa peningkatan kasus Corona di seluruh dunia terus meningkat termasuk Indonesia (KEMENKES, 2021).

Hal ini kemudian dijelaskan bahwa peningkatan mortalitas dan morbiditas kasus COVID-19 diprediksi dari human to human, sesuai dengan kejadian penularan kepada petugas kesehatan yang merawat pasien COVID-19, disertai bukti lain penularan di luar Cina dari seorang yang datang dari Kota Shanghai, Cina ke Jerman dan diiringi penemuan hasil positif pada orang yang ditemui dalam kantor. Pada laporan kasus ini bahkan dikatakan penularan terjadi pada saat kasus indeks belum mengalami gejala (asimtomatik) atau masih dalam masa inkubasi. Laporan lain mendukung penularan antar manusia adalah laporan 9 kasus penularan langsung antar manusia di luar Cina dari kasus index ke orang kontak erat yang tidak memiliki riwayat perjalanan manapun. Penularan ini terjadi umumnya melalui droplet dan kontak dengan virus kemudian virus dapat masuk kedalam mukosa yang terbuka.Suatu analisis mencoba mengukur laju penularan berdasarkan masa inkubasi, gejala dan durasi antara gejala dengan pasien yang diisolasi. Analisis tersebut mendapatkan hasil penularan dari 1 pasien kesekitar 3 orang di sekitarnya, tetapi kemungkinan penularan di masa inkubasi menyebabkan masa kontak pasien ke orang sekitarlebih lama sehingga risiko jumlah kontak tertular dari 1 pasien mungkin dapat lebih besar (Handayani, Hadi, Isbaniah, Burhan, \& Agustin, 2020).

Untuk mengurangi penyebaran COVID19 sangat sulit jika hanya pemerintah dan tenaga kesehatan saja namun diperlukan keterlibatan masyarakat baik dimulai dari perencanaan, pelaksanaan secara sadar patuh protokol kesehatan yaitu dengan ikut terlibat dalam sosialisasi, sering mencuci tangan, menjaga jarak, memakai masker saat keluar rumah, mematuhi pesan yang disampaikan oleh pemerintah seperti Social Distancing (Pembatasan Sosial), Physical Distancing (Pembatasan Fisik), membantu dengan sumbangan Dana dan tenaga (menjadi relawan). Partisipasi masyarakat yang lain penerimaan manfaat dan pengawasan yaitu jika mengalami gejala-gejala demam dan gangguan pernafasan agar segera berobat serta menyampaikan riwayat perjalanan kepada tenaga kesehatan (Mulyadi, 2020).

Melihat hal tersebut maka peneliti tertarik mengetahui partisipasi masyarakat dimulai dari tahap perencanaan, Pelaksanaan, Penerimaan manfaat dan pengawasan dalam pencegahan penyebaran COVID-19 di Wilayah kerja Puskesmas Biru Kab. Bone.

\section{METODE PENELITIAN}

Penelitian ini merupakan penelitian Deskriktif kuantitatif dengan jenis penelitian survey analitik untuk mengetahui hubungan partisipasi masyarakat terhadap pencegahan penyebaran COVID-19 di Wilayah kerja Puskesmas Biru Kab.Bone. Responden dalam penelitian ini sebanyak 397 Responden yang terdiri dari 8 Kelurahan yang menjadi Wilayah Kerja Puskesmas Biru Kab.Bone dengan menggunakan teknik 
Simple Random Sampling. pengumpulan data dilakukan dengan menggunakan kuesioner dengan pertanyaan tertutup, dimana responden bebas menentukan jawaban yang terbaik sesuai dengan pedoman untuk mendapatkan informasi yang lengkap sesuai dengan penelitian yang telah ditentukan. Pengukuran dalam kuesioner menggunakan skala likert dengan keterangan sebagai berikut:

\begin{tabular}{|c|c|c|}
\hline Keterangan & $\begin{array}{l}\text { Skor } \\
\text { Positif }\end{array}$ & $\begin{array}{l}\text { Skor } \\
\text { Negatif }\end{array}$ \\
\hline $\begin{array}{l}\text { Sangat Setuju/ } \\
\text { sesuai/mendukung }\end{array}$ & 5 & 1 \\
\hline $\begin{array}{ll}\text { Setuju/ } & \text { sesuai/ } \\
\text { mendukung } & \end{array}$ & 4 & 2 \\
\hline Ragu-ragu & 3 & 3 \\
\hline $\begin{array}{ll}\text { Tidak setuju/ } & \text { tidak } \\
\text { sesuai/ } & \text { tidak } \\
\text { mendukung } & \\
\end{array}$ & 2 & 4 \\
\hline $\begin{array}{l}\text { Sangat tidak setuju/ } \\
\text { tidak sesuai/ tidak } \\
\text { mendukung }\end{array}$ & 1 & 5 \\
\hline
\end{tabular}

Dari data yang ditemukan kemudian dianalisis secara kuantitatif menggunakan $U j i$ Korelasi Spearman dan Analisis kualitatif dilakukan dengan cara mendeskripsikan dan menginterpretasi fenomena yang ada dilapangan menggunakan Software SPSS 13.00 For Windows Dasar pengambilan keputusan dalam uji Korelasi spearman jika nilai sig <0,05 maka, dapat disimpulkan bahwa terdapat korelasi yang signifikan antara variable yang dihubungkan dan begitupun sebaliknya. Untuk Kriteria tingkat atau kekuatan hubungan (Koofisien korelasi) antara variabel berkisar antara 0,00 sampai 1,00 dengan Kriteria 0,00 - 0,25 : Korelasi sangat lemah, 0,25 - 0,5: Korelasi Cukup, 0,5 $-0,75$ : Korelasi kuat, 0,75 - 0,99 : korelasi sangat kuat dan 1 : Korelasi sempurna.

\section{HASIL DAN PEMBAHASAN}

Penelitian ini dilakukan di Wilayah Kerja Puskesmas Biru Kabupaten Bone, yang terdiri dari 8 kelurahan dengan jumlah sampel sebanyak 397 sampel diperoleh hasil sebagai berikut:

Tabel 1.Distribusi Frekuensi Karakteristik Responden

\begin{tabular}{lccc}
\hline & Variabel & Frekuensi & Persentase (\%) \\
\hline Umur & $15-19$ Tahun & 73 & 18,4 \\
& $20-24$ Tahun & 78 & 19,6 \\
$25-29$ Tahun & 40 & 10,1 \\
& $30-34$ Tahun & 120 & 30,2 \\
& $\geq 35$ Tahun & 86 & 21,7 \\
\hline \multirow{2}{*}{ Jenis Kelamin } & Laki-laki & 213 & 53,7 \\
& Perempuan & 184 & 46,3 \\
\hline
\end{tabular}

Tabel 1 menunjukkan bahwa sebagian besar

berjenis kelamin laki-laki $(53,7 \%)$. responden berumur 30-34 Tahun $(30,2 \%)$ dan

Tabel 2.Distribusi Frekuensi Partisipasi Masyarakat

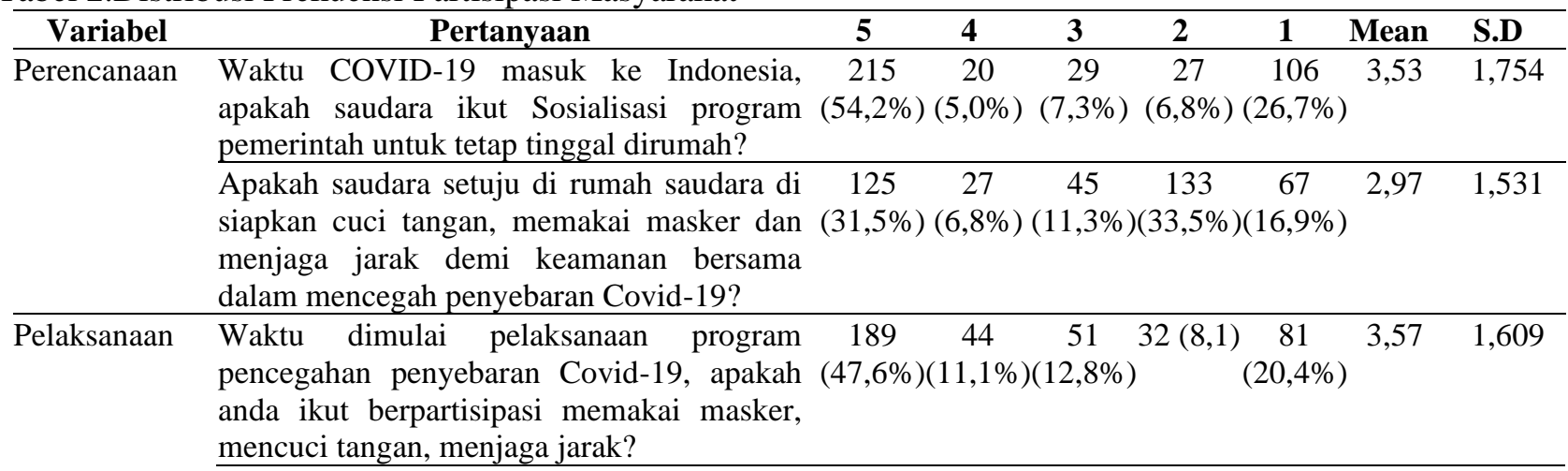




\begin{tabular}{|c|c|c|c|c|}
\hline & $\begin{array}{l}\text { Apakah saudara ikut langsung dalam } \\
\text { membantu pemerintah seperti pembuatan } \\
\text { sarana cuci tangan dan menyediakan masker } \\
\text { di masyarakat sekitar? }\end{array}$ & $\begin{array}{ccccc}95 & 62 & 119 & 40 & 81 \\
(23,9 \%) & (15,6 \%) & (30 \%) & (10,1 \%) & (20,4 \%) \\
\end{array}$ & 3,13 & 1,421 \\
\hline \multirow[t]{2}{*}{ Manfaat } & $\begin{array}{l}\text { Sebelum kasus Covid-19, apakah masyarakat } \\
\text { sadar manfaat yang diperoleh jika Memakai } \\
\text { masker, menjaga jarak dan mencuci tangan? }\end{array}$ & $\begin{array}{ccccc}59 & 123 & 65 & 58 & 92 \\
(14,9 \%) & (31 \%) & (16,4 \%) & (14,6 \%) & (23,2 \%)\end{array}$ & 3,00 & 1,408 \\
\hline & $\begin{array}{l}\text { Apakah saudara terlibat langsung dalam } \\
\text { kelompok masyarakat untuk membantu } \\
\text { masyarakat berupa tenaga maupun materi } \\
\text { seperti membagikan masker dan } \\
\text { handsanitizer? }\end{array}$ & $\begin{array}{ccccc}71 & 67 & 52 & 101 & 106 \\
(17,9 \%)(16,9 \%)(13,1 \%)(25,4 \%)(26,7 \%)\end{array}$ & 2,74 & 1,464 \\
\hline \multirow[t]{2}{*}{ Pengawasan } & $\begin{array}{l}\text { Apakah saudara ingin terlibat dalam } \\
\text { mengawasi lingkungan dan masyarakat agar } \\
\text { Covid-19 tidak menyebar? }\end{array}$ & $\begin{array}{ccccc}63 & 107 & 85 & 54 & 88 \\
(15,9 \%) & (27 \%) & (21,4 \%) & (13,6 \%) & (22,2 \%)\end{array}$ & 3,01 & 1,390 \\
\hline & $\begin{array}{l}\text { Apakah saudara ikut langsung mengawasi } \\
\text { dan melaporkan ketika ada masyarakat luar } \\
\text { masuk ke lingkungan masyarakat atau ada } \\
\text { masyarakat yang munculkan gejala Covid- } \\
19 \text { ? }\end{array}$ & 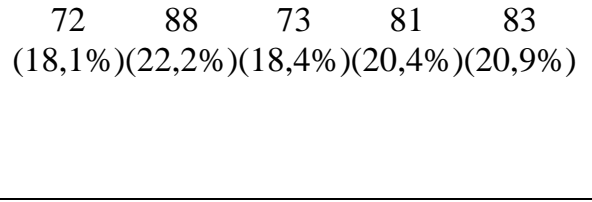 & 2,96 & 1,411 \\
\hline
\end{tabular}

Berdasarkan Tabel 2 menunjukkan dari 397 responden sebanyak $215 \quad(54,2 \%)$ responden yang ikut program pemerintah untuk tetap tinggal di rumah, sebanyak 20 $(5,0 \%)$ responden yang pernah mendengar pemerintah meminta masyarakat untuk tetap tinggal di rumah, sebanyak $29 \quad(7,3 \%)$ responden yang tidak ingat apakah ada informasi dari pemerintah untuk tetap tinggal di rumah, sebanyak $27(6,8 \%)$ responden tidak mendengar adanya program pemerintah untuk tetap tinggal di rumah, dan sebanyak $106(26,7 \%)$ responden tidak mendengar sama sekali program pemerintah untuk tetap tinggal di rumah. Sejak informasi COVID-19 masuk ke Indonesia sebanyak 125 (31,5\%) responden sangat setuju di rumah di siapkan cuci tangan, memakai masker, mencuci tangan, menjagajarak sebagai upaya dalam mencegah penyebaran COVID-19, sebanyak $27(6,8 \%)$ responden setuju di rumah di siapkan cuci tangan, memakai masker, mencuci tangan, menjagajarak sebagai upayadalam mencegah penyebaran COVID19 , sebanyak $45(11,3 \%)$ responden raguragu apakah di rumah perlu di siapkan cuci tangan, memakai masker, mencuci tangan, menjagajarak sebagai upaya dalam mencegah penyebaran COVID-19, sebanyak 133 $(33,5 \%)$ tidak setuju di rumah di siapkan cuci tangan, memakai masker, mencuci tangan, menjagajarak sebagai upaya dalam mencegah penyebaran COVID-19, sebanyak 67 (16,9\&) sangat tidak setuju dirumah di siapkan cuci tangan, memakai masker, mencuci tangan, menjagajarak sebagai upaya dalam mencegah penyebaran COVID-19 jika harus keluar rumah. sebanyak 106 (26,7\%) responden yang antusias dengan adanya pembatasan aktifitas dan sebanyak 119 (30\%) responden yang sangat tidak antusias.

Partisipasi masyarakat dalam pelaksanaan pencegahan penyebaran COVID-19, bahwa sebanyak 189 (47,6\%) responden ikut memakai masker, mencuci tangan, dan menjaga jarak, sebanyak 44 $(11,1 \%)$ responden hanya ikut memakai masker dan mencuci tangan, sebanyak 63 $(15,9 \%)$ responden hanya memakai masker, sebanyak $49(12,3 \%)$ responden hanya mengikuti salah satu dari memakai masker, mencuci tangan, dan menjaga jarak, dan sebanyak $81 \quad(20,4 \%)$ responden tidak mengikuti sama sekali protokol kesehatan hal ini di sebabkan oleh kesadaran dan kepedulian akan pelaksanaan pencegahan penyebaran COVID-19. Hal ini dibuktikan dengan jumlah masyarakat yang ikut langsung dalam membantu pemerintah dalam menerapkan protokol kesehatan yaitu sebanyak $95 \quad(23,9 \%)$ responden ikut langsung terlibat dalam pembuatan sarana cuci tangan dan menyediakan masker di masyarakat sekitar, sebanyak $62 \quad(15,6 \%)$ hanya terlibat dalam dana, ide dan usulan, sebanyak 119 (30\%) responden hanya setuju dengan program pemerintah tetapi tidak terlibat dalam mencegah penyebaran 
COVID-19, sebanyak $40 \quad(10,1 \%)$ responden tidak ikut terlibat dan sebanyak 81 $(20,4 \%)$ responden tidak setuju sama sekali.

Partisipasi masyarakat dalam penerimaan dan manfaat hasil pencegahan penyebaran COVID-19, pemerintah membuka secara sukarela dan sadar adanya penerpaan protokol kesehatan. Hal ini dibuktikan oleh pernyataan masyarakat yaitu sebanyak $59(14,9 \%)$ responden merasa sangat penting, sebanyak $123 \quad(31 \%)$ responden merasa penting, sebanyak 65 $(16,4 \%)$ responden ragu-ragu, sebanyak 58 $(14,6 \%)$ responden merasa terpaksa dan sebanyak $92(23,2 \%)$ responden merasa tidak penting sama sekali. Menurut pernyataan beberapa informan menyatakan bahwa masyarakat sering memakai masker dan menyediakan masker untuk dirinya sendiri dan orang lain. Hal ini di buktikan dari hasil tabel yang menyatakan bahwa sebanyak 71 $(17,9 \%)$ responden ikut terlibat langsung dalam kelompok masyarakat, sebanyak 67 $(16,9 \%)$ responden ikut terlibat namun tidak langsung dalam kelompok masyarakat, sebanyak $52(13,1 \%)$ responden yang merasa tidak tahu terlibat atau tidak dalam kelompok masyarakat, sebanyak $101 \quad(25,4 \%)$ responden tidak terlibat dalam kelompok masyarakat, sebanyak $106 \quad(26,7 \%)$ responden tidak mau terlibat dalam kelompok masyarakat untuk membantu masyarakat berupa tenaga maupun materi seperti membagikan masker dan handsanitizer.

Partisipasi masyarakat dalam pengawasan pencegahan penyebaran COVID-19, dari 397 responden sebanyak 63 $(15,9 \%)$ responden ingin terlibat dalam mengawasi lingkungan dan masyarakat agar COVID-19 tidak menyebar, sebanyak 107 (27\%) responden mau terlibat dalam mengawasi lingkungan dan masyarakat agar COVID-19 tidak menyebar, sebanyak 85 $(21,4 \%)$ responden tidak tahu harus terlibat atau tidak mengawasi lingkungan dan masyarakat agar COVID-19 tidak menyebar, sebanyak $54(13,6 \%)$ responden merasa tidak perlu dilibatkan mengawasi lingkungan dan masyarakat agar COVID-19 tidak menyebar, sebanyak $88(22,2 \%)$ responden tidak mau dilibatkan dalam mengawasi lingkungan dan masyarakat agar COVID-19 tidak menyebar. kurangnya minat masyarakat untuk terlibat dalam mengawasi pencegahan penyebaran COVID-19 karena kesibukan masyarakat dalam mencari nafkah untuk keluarganya sesuai dengan pernyataan beberapa responden. Hal ini dibuktikan dari hasil tabel sebanyak $72(18,1 \%)$ responden ikut langsung mengawasi dan melaporkan, sebanyak $88(22,2 \%)$ responden ikut namun tidak lansgung mengawasi dan melaporkan, sebanyak $73(18,4 \%)$ responden tidak tahu terlibat atau tidak dalam mengawasi dan melaporkan, sebanyak $81(20,4 \%)$ responden tidak ikut terlibat dalam mengawasi dan melaporkan serta sebanyak $83 \quad(20,9 \%)$ responden tidak mau terlibat dalam pengawasan dan melaporkan ketika ada masyarakat luar masuk ke lingkungan masyarakat atau ada masyarakat yang munculkan gejala COVID-19.

Tabel 3.Hubungan Partisipasi Masyarakat dengan Pencegahan Penyebaran COVID-19

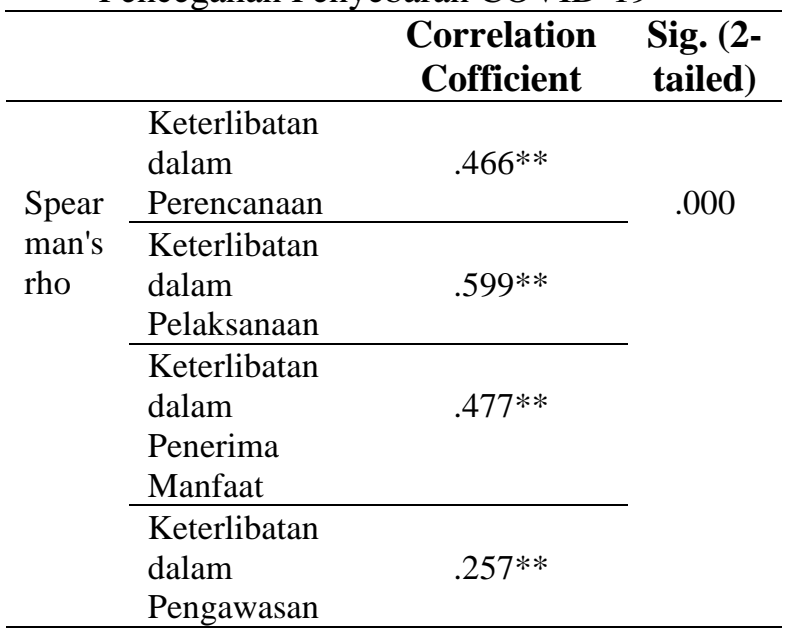

Tabel 3 Menunjukkan bahwa Nilai signifikan yang diperoleh dari setiap Variabel sebesar $0,000<\operatorname{sig} 0,05$ yang berarti terdapat hubungan antar kedua variable dimana variabel tersebut mempunyai dua arah (2tailed) dan bernilai positif. Sedangkan nilai kofisien korelasi dari masing - masing variabel antara Keterlibatan Masyarakat dalam Perencanaan dengan Pencegahan Penyebaran COVID-19 memperoleh nilai $0,466^{* *}$ yang berarti memilki hubungan cukup kuat, Keterlibatan Masyarakat dalam Pelaksanaan dengan Pencegahan Penyebaran COVID-19 
memperoleh nilai $0,599 * *$ yang berarti memiliki hubungan yang cukup kuat, Keterlibatan Masyarakat dalam Penerimaan manfaat dengan Pencegahan Penyebaran COVID-19 memperoleh nilai 0,477 yang berarti memiliki hubungan yang cukup kuat, Keterlibatan Masyarakat dalam Pengawasan dengan Pencegahan Penyebaran COVID-19 memperoleh nilai 0,257 yang berarti memiliki hubungan yang Cukup kuat Sehingga kesimpulan dari keempat variable partisipisi masyarakat memiliki hubungan dengan pencegahan penyebaran COVID-19 di Wilayah Kerja Pukesmas Biru yaitu semakin tinggi Tingkat partisipasi masyarakat maka maka semakin tinggi pencegahan penyebaran COVID-19

\section{Keterlibatan Masyarakat dalam Perencanaan}

Tahapan Partisipasi masyarakat dimulai dari perencanaan, Pelaksanaan, Penerimaan Manfaat, dan Pengawasan atau evaluasi hasil. Tahap Perencanaan merupakan proses untuk menentukan langkah yang harus ditempuh dan mengidentifikasi berbagai kebutuhan secara efektif dan efisien (Hadiutomo, 2021). Keterlibatan masyarakat Wilayah Kerja Puskesmas Biru dalam Perencanaan Pencegahan Penyebaran COVID-19 dimulai sejak ikut berpartisipasi dalam sosialisasi anjuran Pemerintah untuk tetap tinggal dirumah dan bekerja dirumah, masyarakatpun setuju dalam pembuatan cuci tangan, memakai masker dan menjaga jarak yaitu sebanyak $125 \quad(31,5 \%)$ responden.dan sebaliknya sebanyak $133(33,5 \%)$ responden yang tidak setuju di rumah disiapkan cuci tangan, memakai masker saat keluar rumah dan menjaga jarak. Masyarakat yang terlibat dalam perencanaan didasari oleh pemahaman masyarakat bahwa Permasalahan COVID-19 bukanlah masalah hanya sekelompok Individu melainkan merupakan masalah bersama, paparan informasi terkait COVID19 pula yang menggerakkan masyarakat dalam melakukan kegiatan pencegahan penyebaran dan mengurangi dampak yang bisa ditimbulkan di masyarakat (Sitohang, Rahadian, \& Prasetyoputra, 2020).

Hasil Uji Statistik Menggunakan Uji Korelasi Spearman, antara Keterlibatan Masyarakat dalam perencanaan dengan pencegahan penyebaran COVID-19 diperoleh nilai $r$ hitung sebesar $0,466^{* *}$ yang berarti terdapat hubungan yang cukup kuat antar variabel dengan nilai sig 0,000 dengan nilai positif yaitu semakin terlibat masyarakat dalam perencanaan maka akan semakin berhasil pencegahan penyebaran COVID-19. Perencanaan Pencegahan penyebaran COVID-19 sangat dibutuhkan untuk meminimalkan risiko penyebaran COVID-19 secara dini dimasyarakat.

\section{Keterlibatan Masyarakat dalam Pelaksanaan}

Pelaksanaan adalah suatu tindakan yang dilakukan dari sebuah rencana yang sudah di susun secara matang dan terperinci. Menurut Saqlain et al. (2020) Tindakan protokol kesehatan yang ditetapkan oleh World Health Organization dan Kementerian Kesehatan RI tidak akan berjalan sebelum masyarakat dibekali dengan pengetahuan, sikap dan perilaku yang baik dalam pelaksanaannya. Menurut Rumengan, Ruru, and Londa (2021), dari pandemi yang terjadi saat ini Masyarakat mempersiapkan diri secara mandiri dengan membawa alat pelindung diri berupa masker dan hand sanitizer dan menjaga jarak saat berada di keramaian. Selain itu, masyarakat secara sukarela memberikan sumbangan kepada masyarakat lain berupa tenaga dengan bekerjasama dalam pembuatan cuci tangan dan sumbangan berupa materi dengan membagikan masker kepada masyarakat sekitar.

Hasil Uji Statistik Menggunakan Uji Korelasi Spearman, antara Keterlibatan Masyarakat dalam pelaksanaan dengan pencegahan penyebaran COVID-19 diperoleh nilai $\mathrm{r}$ hitung sebesar $0,599 * *$ yang berarti terdapat hubungan yang cukup kuat antar variabel dengan nilai sig 0,000 dengan nilai positif yaitu semakain tinggi tingkat partisipasi masyarakat dalam pelaksanaan Protokol kesehatan, physical Distancing, Self Quarantine dan Self Isolasi maka semakin tinggi Pencegahan Penyebaran COVID-19. Menurut Liu et al. (2020) penatalaksanaan yang harus diterapkan oleh seluruh 
masyarakat untuk memperlambat dan mencegah penyebaran COVID-19 yaitu dengan menggunakan masker, tidak melakukan kontak fisik, menjaga jarak, rajin cuci tangan, selalu membawa antiseptik dan masker.

\section{Keterlibatan Masyarakat dalam Penerimaan Manfaat}

Keterlibatan masyarakat dalam penerima manfaat unsur yang sangat penting yang sering terlupakan. Kebermanfaatan mematuhi protokol kesehatan dan senangtiasa penerapan protokol kesehatan, physical Distancing, Self Quarantine dan Self Isolasiuntuk mewujudkan masyarakat yang terhindar dari penyebaran Virus COVID-19. Keterlibatan masyarakat Wilayah Kerja Puskesmas Biru dalam Penerimaan manfaat dalam Pencegahan Penyebaran COVID-19 yaitu dengan pembagian masker dan Hand sanitizer. Kesadaran masyarakat tentang pentingnya mematuhi protokol kesehatan terbilang cukup yaitu sebanyak 123 (31\%) respondenyang sadar manfaat dari Protokol kesehatan. Namun,sebanyak $101 \quad(25,4 \%)$ responden tidak terlibat langsung dalam kelompok masyarakat, sebanyak 106 (26,7\%) responden tidak ingin terlibat dalam kelompok masyarakat yang membantu masyarakat lain. Hal ini disebabkan selain dari kurangnya pengetahuan masyarakat sehingga mempengaruhi sikap dan perilakunya juga masyarakat belum merasakan manfaat dari protokol kesehatan ditambah kesibukan masyarakat dalam memenuhi kebutuhan sehari-hari. Menurut Susanto and Kramadibrata (2020), partisipasi masyarakat dipengaruhi oleh karakteristik individu itu sendiri seperti pendidikan, umur, pekerjaan, pendapatan dan jumlah beban keluarga.Masyarakat yang sudah sadar akan manfaat yang diperoleh jika menerapkakn protokol kesehatan akan merasa aman dan nyaman karena dapat mencegah penyebaran COVID-19. Hal ini sejalan dengan penelitian oleh Jose et al. (2021), menyatakan bahwa masyarakat merasa akan dapat mencegah penularan COVID-19 dengan menerapkan protokol kesehatan yang diwajibkan oleh pemerintah.

Hasil Uji Statistik Menggunakan Uji
Korelasi Spearman, antara Keterlibatan Masyarakat dalam Penerimaan Manfaat dengan pencegahan penyebaran COVID-19 diperoleh nilai $r$ hitung sebesar $0,477 * *$ yang berarti terdapat hubungan yang cukup kuat antar variabel dengan nilai sig 0,000 dengan nilai positif yaitu semakin tinggi tingkat partisipasi masyarakat dalam penerimaan manfaat maka semakin tinggi pencegahan penyebaran COVID-19. Hal ini sesuai dengan penelitian sebelumnya yang menjelaskan bahwa Jika manfaat yang dirasakan dari suatu tindakan pencegahan penyakit rendah maka kemungkinan tindakan yang dilakukan tersebut semakin rendah. Jadi jika manfaat dirasakan tinggi maka individu tersebut akan mengambil tindakan untuk mencegah penyebaran penyakit jika mereka percaya bahwa manfaat dari tindakan yang diambil tersebut bermanfaat untuk menjaga dirinya sendiri dan orang lain (Hall, 2012).

\section{Keterlibatan Masyarakat dalam Pengawasan}

Tahap pengawasan sangat di butuhkan karena untuk mengetahui tindakan dan koreksian sehingga bisa segera ditindaklanjuti. Seperti yang dijelaskan oleh Theresia;, S.Andini; Nugraha; and Mardikanto (2004), bahwa pemantauan dan Evaluasi program sangat penting, bukan saja agar tujuan tercapai sesuai yang diharapkan akan tetapi diperlukan untuk memperoleh masukan tentang masalah-masalah dan kendala yang dihadapi sebelumnya. Masyarakat Wilayah kerja Puskesmas Biru dominasi oleh masyarakat yang ingin ikut terlibat dalam pengawasan yaitu sebanyak 107 (27\%) responden dan rata-rata masyarakat ikut baik secara langsung maupun tidak dalam pengawasan. Keterlibatan masyarakat Wilayah Kerja Puskesmas Biru dalam Pengawasan Pencegahan Penyebaran COVID-19 yaitu dengan saling mengawasi antar warga untuk patuh protokol kesehatan dan melapor jika ada masyarakat luar yang masuk lingkungan masyarakat atau dengan memantau masyarakat yang dianjurkan untuk isolasi mandiri atau ada warga yang terkonfirmasi atau belum COVID-19.

Hasil Uji Statistik Menggunakan Uji 
Health Care : Jurnal Kesehatan 10(2) Desember 2021 (322-330)

Korelasi Spearman, antara Keterlibatan Masyarakat dalam Pengawasam dengan pencegahan penyebaran COVID-19 diperoleh nilai $r$ hitung sebesar $0,257 * *$ yang berarti terdapat hubungan antar variabel dengan nilai sig 0,000 dengan nilai positif yaitu semakin tinggi tingkat partisipasi masyarakat dalam pengawasan maka semakin tinggi pencegahan penyebaran COVID-19. Hal ini sesuai dengan penelitian yang dilakukan oleh Sumampouw (2020), meskipun masyarakat telah melakukan protokol kesehatan namun perlu dilakukan pengawasan secara terus menerus dan masif agar dapat menekan laju peningkatan COVID-19.

\section{SIMPULAN}

Setelah melakukan penelitian dan analisa maka dapat disimpulkan bahwa Partisipasi masyarakat Wilayah Kerja Puskesmas Biru mulai dari Partisipasi masyarakat dalam perencanaan, Pelaksanaan, Penerimaan manfaat, dan pengawasan masih termasuk dalam kategori cukup dalam mencegah penyebaranCOVID-19. Maka dari itu, untuk meningkatkan partisipasi masyarakat tersebut dibutuhkan pendekatan-pendekatan yang efektif untuk memberikan pengetahuan, meningkatkan kepedulian dan kesadaran masyarakat. Selanjutnya untuk mengurangi jumlah kasus COVID-19 dibutuhkan kerjasama yang baik antara Pemerintah, Petugas Kesehatan dan Masyarakat.

\section{DAFTAR PUSTAKA}

Hadiutomo, K. (2021). Perencanaan Pembangunan Terintegrasi dan Terdesentralisasi. Yogyakarta: CV. Budi Utama.

Hall, K. S. (2012). The health belief model can guide modern contraceptive behavior research and practice. Journal of midwifery \& women's health, 57(1), 74-81.

Handayani, D., Hadi, D. R., Isbaniah, F., Burhan, E., \& Agustin, H. (2020). Corona Virus Disease 2019. Jurnal Respirologi Indonesia, 40(2).

Jose, R., Narendran, M., Bindu, A., Beevi, N., Manju, L., \& Benny, P. (2021). Public perception and preparedness for the pandemic COVID 19: a health belief model approach. Clinical Epidemiology and Global Health, 9, 41-46.

KEMENKES. (2021). Update Virus Corona Disease. .

KEPRES. (2020). Penetapan Kedaruratan Kesehatan Masyarakat Corona Virus Disease 2019 (COVID-19).

Liu, F., Wang, W., Yu, H., Wang, Y., Wu, W., Qin, X., ... Association, C. M. (2020). Prevention and control strategies of general surgeons under COVID-19 pandemic. Surgery in Practice and Science, 100008.

Mulyadi, M. (2020). Partisipasi Masyarakat Dalam Penanganan Penyebaran Covid19. Bidang Kesejahteraan Sosial, XII(No.8).

Rumengan, C., Ruru, J., \& Londa, V. (2021). Partisipasi Masyarakat Pada Pencegahan Dan Penaggulangan Virus Corona Di Kelurahan Teling Atas Kecamatan Wanea Kota Manado. JURNAL ADMINISTRASI PUBLIK, 7(102).

Saqlain, M., Munir, M. M., Rehman, S. U., Gulzar, A., Naz, S., Ahmed, Z., . . . Mashhood, M. (2020). Knowledge, attitude, practice and perceived barriers among healthcare workers regarding COVID-19: a cross-sectional survey from Pakistan. Journal of Hospital Infection, 105(3), 419-423. doi: 10.1016/j.jhin.2020.05.007

Sitohang, M. Y., Rahadian, A. S., \& Prasetyoputra, P. (2020). Inisiatif Masyarakat Indonesia Di Masa Awal Pandemi Covid-19: Sebuah Upaya Pembangunan Kesehatan. Jurnal Kependudukan Indonesia, 33-38.

Sumampouw, O. J. (2020). Pelaksanaan Protokol Kesehatan Corona Virus Disease 2019 Oleh Masyarakat di Kabupaten Minahasa Tenggara. Sam Ratulangi Journal of Public Health, 1(2).

Susanto, A. H., \& Kramadibrata, B. S. (2020). Pengaruh Partisipasi Masyarakat Dan Kebijakan Pemerintah Terhadap 
Pengurangan Penyebaran Virus Covid 19. JISIP (Jurnal Ilmu Sosial dan Pendidikan), 4(4).

Theresia;, A., S.Andini;, K., Nugraha;, P. G. P., \& Mardikanto, T. (2004). Pembangunan Berbasis Masyarakat : Acuan Bagi Praktisi, Akademis, dan Pemerhati Pengembangan Masyarakat. Bandung: Alfabeta.

WHO. (2020). Update Corona Virus Disease. 